\title{
CORRELATION BETWEEN EPICARDIAL FAT THICKNESS BASED ON MULTI SLICE COMPUTED-TOMOGRAPHY SCAN THORAX WITH THE WAIST CIRCUMFERENCE AND BODY MASS INDEX ON PATIENTS WITH NON- DIABETIC DYSLIPIDEMIA
}

\author{
Yenny Wendy, Mirna Muis, Sri Asriyani \\ Departement of Radiology, Faculty of Medicine, Hasanuddin University \\ Correspondence author: \\ Yenny Wendy \\ Department of Radiology, Faculty of Medicine, Hasanuddin University \\ Email: yennywendy87@,gmail.com
}

\section{Article Info: \\ Received: 22 May 2018 \\ Revised: 25 May 2018 \\ Accepted: 30 June 2018 \\ Available online: 31 December 2018}

Keywords: Epicardial fat, MSCT scan Thorax, waist circumference, BMI

DOI: $10.20956 / n m s j . v 3 i 1.5774$

\begin{abstract}
Introduction: Epicardial fat is a visceral fat that plays a role in cardiovascular disease. Dyslipidemia non-diabetes mellitus can be found in both obese and non-obese patients. Measurement of waist circumference and body mass index (BMI) can assess the central and peripheral obesity. This study aimed to investigate the correlation between epicardial fat thickness based on multi slice computed-tomography (MSCT) scan Thorax with the waist circumference and BMI on patients with non-diabetic dyslipidemia.

Methods: We cross-sectionally recruited 57 adult patients (28-70 years) with non-diabetic dyslipidemia, from the clinic of Department of Radiology, Wahidin Sudirohusodo Hospital, between December 2017 to February 2018. Majority of our participants came from the age group of 45 to 64 years, with the mean epicardial fat was $6.37( \pm \mathrm{XX}) \mathrm{mm}$, and ranged from 2.80 to $10.80 \mathrm{~mm}$. Data were analyzed using the Mann-Whitney and Spearman correlation tests. Results: We found a significant correlation between the waist circumference and epicardial fat $(r=0.286, p=0.031)$, but this correlation was not statistically significant between BMI and epicardial fat. In sub-group analysis, there was no difference in the mean of epicardial fat thickness by sex.

Conclusion: There is a correlation between waist circumference and epicardial fat in patients with dyslipidemia non-diabetes mellitus.
\end{abstract}

\section{Pendahuluan}

Selama beberapa tahun terakhir, lemak epikardial dianggap berhubungan erat dengan pembuluh darah koroner, baik secara anatomis maupun fungsional. Akumulasi bukti memperlihatkan bahwa lemak epikardial dapat dikaitkan dengan perkembangan aterosklerosis koroner melalui beberapa mekanisme parakrin sebagai mediator inflamasi lokal yang memicu proses aterosklerotik, dan efek sistemik lainnya.
Oleh karena itu, penebalan jaringan adiposa epikardial dapat dipertimbangkan sebagai salah satu faktor risiko penyakit kardiovaskular, yang merupakan target terapeutik potensial, dan merupakan jembatan yang menghubungkan endokrin-kardiologi. ${ }^{1-3}$

Indeks Massa Tubuh (IMT) dan lingkar pinggang merupakan pemeriksaan antropometri yang disarankan pada pasien dengan berat badan berlebih untuk menilai jenis obesitasnya. IMT dapat menilai status gizi seseorang. Metode ini 
tidak mahal dan mudah untuk dilakukan sebagai indikator status gizi dan digunakan untuk skrining berat badan. ${ }^{4}$

Lingkar pinggang dapat digunakan untuk menentukan obesitas visceral sentral. Kriteria obese untuk populasi Asia Pasifik yaitu $\geq 90 \mathrm{~cm}$ untuk pria, dan $\geq 80 \mathrm{~cm}$ untuk wanita. Lingkar pinggang terbukti dapat mendeteksi obesitas sentral dan sindrom metabolik dengan ketepatan yang cukup tinggi dibandingkan IMT dan lingkar panggul. ${ }^{5,6}$

Adapun pengukuran ketebalan lemak epikardial yang akurat dapat dilakukan dengan menggunakan Multi Slice ComputedTomography (MSCT) scan Thorax dikarenakan tingginya resolusi spasial dengan modalitas ini. ${ }^{1,7}$

Dislipidemia merupakan faktor risiko primer untuk penyakit jantung koroner. Semua fraksi lipid mempunyai peranan penting dalam proses terjadinya aterosklerosis dan erat kaitannya antara satu dengan yang lain. Terdapat hubungan yang kuat antara dislipidemia dan penyakit kardiovaskular yang relatif setara antara populasi Asia dan non-Asia di wilayah Asia Pasifik. $^{6}$

Saat ini, penelitian dan data mengenai korelasi ketebalan lemak epikardial pada $M S C T$ scan Thorax dengan lingkar pinggang dan IMT pada pasien dislipidemia non-diabetes mellitus masih relatif jarang di Indonesia. Oleh karena itu, kami melaksanakan penelitian ini untuk menentukan korelasi antara ketebalan lemak epikardial berdasarkan MSCT scan Thorax dengan lingkar pinggang dan IMT pada penderita dislipidemia non-diabetes.

\section{METODE}

Penelitian ini menggunakan desain cross-sectional. Pasien non-diabetes dengan kelainan profil lipid sebanyak 57 orang menjalani pemeriksaan MSCT Scan Thorax tanpa dan dengan kontras di Bagian Radiologi Rumah Sakit Wahidin Sudirohusodo pada bulan Desember 2017 sampai Februari 2018. Kriteria inklusi adalah sebagai berikut.

Pasien tidak diikut-sertakan dalam penelitian, jika menolak untuk menandatangani informed consent. Penelitian ini telah mendapat persetujuan dari Komite Etik Fakultas Kedokteran Universitas Hasanuddin.

\section{Metode Statistik}

Analisis data terdiri dari analisis deskriptif dan analisis statistik. Analisis deskriptif dilakukan untuk melihat distribusi profil pasien berdasarkan umur dan jenis kelamin. Untuk menilai hubungan antara lingkar pinggang dan IMT dengan ketebalan lemak epikardial, digunakan uji korelasi Spearman. Hasil uji dikatakan bermakna secara statistik jika nilai $\mathrm{p}<0,05$.

Tabel 1. Karakteristik Pasien

\begin{tabular}{llll}
\hline Variabel & & $\mathbf{N}$ & $\mathbf{\%}$ \\
\hline \multirow{2}{*}{ Jenis kelamin } & Laki-laki & 42 & 73,7 \\
& Perempuan & 15 & 26,3 \\
& & & \\
Umur (tahun) & $20-44$ & 13 & 22,8 \\
& $45-64$ & 29 & 50,9 \\
& $\geq 65$ & 15 & 26,3 \\
\hline
\end{tabular}

Dari Tabel 1 dapat dilihat bahwa dan berada pada rentang umur 45-64 tahun mayoritas subjek adalah laki-laki $(n=42 ; 73,7 \%), \quad(50,9 \%)$. 
Tabel 2. Distribusi Lingkar Pinggang berdasarkan Jenis Kelamin

\begin{tabular}{lccc}
\hline & & \multicolumn{1}{l}{ Lingkar Pinggang } \\
& & & \\
\cline { 2 - 4 } & Jenis Kelamin & Normal & Total \\
& & $\mathbf{N}(\%)$ & $\mathbf{N}(\%)$ \\
\cline { 2 - 4 } & & $\mathbf{N}(\%)$ & $42(73,7)$ \\
\hline Laki-laki & $28(49,2)$ & $14(24,5)$ & $15(26,3)$ \\
\hline Total & $6(10,6)$ & $9(15,7)$ & $57(100)$ \\
\hline
\end{tabular}

Tabel 2 memperlihatkan distribusi 40,2\% pasien yang memiliki lingkar pinggang lingkar pinggang subjek penelitian. Dari total berlebih, $24,5 \%$ adalah laki-laki.

Tabel 3. Distribusi IMT

\begin{tabular}{lrr}
\hline \multicolumn{1}{c}{ IMT } & N & $\mathbf{\%}$ \\
\hline Underweight & 17 & 29,8 \\
Normal & 19 & 33,4 \\
Overweight & 9 & 14,8 \\
Obese I & 11 & 19,3 \\
Obese II & 1 & 1,7 \\
\hline Total & 57 & 100 \\
\hline
\end{tabular}

Tabel 3 memperlihatkan distribusi IMT subjek penelitian. Dari 57 pasien, yang terbanyak adalah dengan IMT normal (33,4\%), underweight $(29,8 \%)$, dan obese I (19,3\%).

Tabel 4 memperlihatkan perbedaan ratarata lemak epikardial berdasarkan jenis kelamin. Ketebalan lemak epikardial pada laki-laki berada pada nilai 2,80-10,30 $\mathrm{mm}$, sedangkan pada perempuan 3,50-10,80 mm. Berdasarkan hasi uji Mann-Whitney, tidak ada perbedaan rata-rata ketebalan lemak epikardial antara kelompok lakilaki dengan perempuan $(6,20$ vs. $6,50 \mathrm{~mm} ; \mathrm{p}=$ 0,289 ).

Selanjutnya, kami juga melakukan uji statistik untuk menilai adanya korelasi antara umur dengan ketebalan lemak epikardial (Tabel 5), korelasi antara lingkar pinggang dengan ketebalan lemak epikardial (Tabel 6), dan korelasi antara IMT dengan ketebalan lemak epikardial (Tabel 7).

Tabel 5 memperlihatkan korelasi antara umur dengan ketebalan lemak epikardial. Dari data yang kami peroleh, bertambahnya umur berbanding lurus dengan pertambahan rerata lemak pericardial, meskipun korelasi tersebut tidak signifikan $(\mathrm{p}=0,906)$.

Tabel 6 memperlihatkan korelasi antara lingkar pinggang dengan ketebalan lemak epikardial. Pasien dengan lingkar pinggang berlebih memiliki rerata lemak epikardial yang lebih tebal $(6,98 \mathrm{~mm})$ dibandingkan pasien dengan lingkar pinggang normal $(5,71 \mathrm{~mm})$. Dari hasil uji Spearman, didapatkan bahwa korelasi tersebut bermakna, dengan $\mathrm{p}=0,031$, dengan kekuatan korelasi lemah $(\mathrm{r}=0,286)$ dan arah korelasi positif. 
Tabel 7 memperlihatkan korelasi IMT dengan ketebalan lemak epikardial.. Nilai rerata lemak epikardial pada kelompok obese I $(7,4$ $\mathrm{mm})$ lebih tebal dibandingkan dengan mereka yang memiliki IMT normal $(5,9 \mathrm{~mm})$ dan overweight $(6,1 \mathrm{~mm})$; walaupun secara statistik tidak bermakna $(\mathrm{p}=0,162)$. Menariknya, kelompok pasien dengan IMT "underweight" $(6,3 \mathrm{~mm})$ juga memiliki rerata lemak yang lebih tebal jika dibandingkan dengan kelompok IMT normal dan overweight.

Tabel 4. Perbedaan Rata-rata Lemak Epikardial (mm) berdasarkan Jenis Kelamin

\begin{tabular}{lcccccc}
\hline \multirow{2}{*}{ Jenis Kelamin } & \multirow{2}{*}{ N } & \multicolumn{5}{c}{ Lemak Epikardial } \\
\cline { 3 - 7 } & & Min & Max & Rerata & Median & SD \\
\hline Laki-laki & 42 & 2,80 & 10,30 & 6,20 & 5,70 & 1,70 \\
Perempuan & 15 & 3,50 & 10,80 & 6,50 & 6,60 & 2,11 \\
\hline
\end{tabular}

Uji Mann-Whitney, $\mathrm{p}=0,289$.

Tabel 5. Korelasi Antara Umur (tahun) dengan Lemak Epikardial (mm)

\begin{tabular}{ccccccc}
\hline \multirow{2}{*}{ Umur } & \multirow{2}{*}{$\mathbf{N}$} & \multicolumn{5}{c}{ Lemak Epikardial } \\
\cline { 3 - 7 } & & Min & Max & Rerata & Median & SD \\
\hline $20-44$ & 13 & 4,10 & 9,00 & 6,31 & 6,20 & 1,40 \\
$45-64$ & 29 & 2,80 & 10,80 & 6,37 & 5,80 & 1,98 \\
$\geq 65$ & 15 & 3,40 & 9,50 & 6,45 & 6,50 & 1,64 \\
\hline
\end{tabular}

Uji Spearman, $\mathrm{p}=0,906$.

Tabel 6. Korelasi antara Lingkar Pinggang dengan Lemak Epikardial (mm)

\begin{tabular}{lcccccc}
\hline \multirow{2}{*}{ Lingkar Pinggang } & \multirow{2}{*}{ N } & \multicolumn{5}{c}{ Lemak Epikardial } \\
\cline { 3 - 7 } & & Min & Max & Rerata & Median & SD \\
\hline Normal & 31 & 2,80 & 8,80 & 5,71 & 5,70 & 1,51 \\
Berlebih & 26 & 4,50 & 10,80 & 6,98 & 6,80 & 1,93 \\
\hline
\end{tabular}

Uji Spearman, $\mathrm{p}=0,031 ; \mathrm{r}=0,286$.

Tabel 7. Korelasi Antara IMT dengan Lemak Epikardial (mm)

\begin{tabular}{lcccccc}
\hline \multirow{2}{*}{ IMT } & \multirow{2}{*}{$\mathbf{N}(\%)$} & \multicolumn{5}{c}{ Lemak Epikardial } \\
\cline { 3 - 7 } & & Min & Max & Rerata & Median & SD \\
\hline Underweight & $16(28,1)$ & 3,4 & 9,2 & 6,3 & 5,8 & 1,8 \\
Normal & $20(35,1)$ & 4,0 & 9,3 & 5,9 & 5,7 & 1,3 \\
Overweight & $9(15,8)$ & 2,8 & 9,8 & 6,1 & 5,7 & 2,1 \\
Obese I & $11(19,3)$ & 4,9 & 10,8 & 7,4 & 7,2 & 1,8 \\
Obese II & $1(1,8)$ & - & - & - & - & - \\
\hline
\end{tabular}

Ket : Sampel Obese II sebanyak 1 orang dengan nilai lemak epikardial 5,6 mm

Uji Spearman, $\mathrm{p}=0,162$.

Keterangan : $\mathrm{N}=$ jumlah sampel 


\section{PEMBAHASAN}

Pada studi ini, kami menemukan bahwa terdapat korelasi bermakna (dengan arah korelasi positif) antara lingkar pinggang dengan ketebalan lemak epikardial $(\mathrm{p}=0,031)$. Namun, pada analsis IMT dan lemak epikardial, korelasi bermakna tidak ditemukan.

Pada penelitian ini, mayoritas $(72,3 \%)$ partisipan kami adalah laki-laki. Hal ini disebabkan sebagian besar sampel yang datang untuk menjalani pemeriksaan MSCT scan Thorax disertai dengan riwayat batuk lama. Keluhan batuk lama ini paling sering didapatkan pada kelompok jenis kelamin lakilaki, dengan riwayat merokok ataupun paparan inhalasi debu yang sudah berlangsung lama pada lingkungan kerja.

Dari hasil uji statistik, tidak didapatkan perbedaan rata-rata ketebalan lemak epikardial pada kelompok laki-laki maupun perempuan $(6,20$ vs. $6,50 \mathrm{~mm}$; $\mathrm{p}=0,252$ ). Hasil yang sama juga didapatkan pada peneltian yang dilakukan oleh Piordomenico dkk. yang melibatkan 174 subjek Kaukasian yang menderita hipertensi, dengan IMT dan lingkar pinggang normal. Mereka menemukan bahwa tidak ada korelasi antara jenis kelamin dengan ketebalan lemak epikardial.

Selanjutnya, pada analisis sub-grup, kami juga mendapatkan bahwa tidak ada korelasi bermakna antara ketebalan lemak epikardial dengan kelompok umur tertentu $(p=0,906)$. Hasil yang sama juga dibuktikan pada penelitian yang dilakukan oleh Reiner dkk. Nilai ketebalan lemak epikardial pada ventrikel kanan anterior meningkat sesuai dengan umur hingga usia 20-40 tahun dan setelahnya tidak dipengaruhi oleh umur. Menurut Bertaso dkk., ketebalan lemak epikardial meningkat $22 \%$ pada individu yang berusia lebih dari 65 tahun. Hal tersebut sesuai dengan yang didapatkan pada penelitian ini. Selama proses penuaan, terdapat penurunan massa otot dan peningkatan massa lemak, diikuti dengan distribusi jaringan lemak pada tubuh dan organ viseral. Perubahan ini dialami pada pria maupun wanita dengan redistribusi terbesar pada wanita yang lebih tua. ${ }^{9}$

Hasil uji statistik untuk menilai lingkar pinggang dengan ketebalan lemak epikardial dilakukan dengan uji korelasi Spearman. Terdapat korelasi bermakna dengan arah korelasi positif dengan kekuatan korelasi lemah ( $p=0,031 ; r=0,286)$ pada pasien dislipidemia non-diabetes mellitus, dimana dapat dilihat bahwa semakin meningkat ukuran lingkar pinggang maka ketebalan lemak epikardial juga akan semakin bertambah. Ghaderi dkk. menuliskan bahwa ketebalan lemak perikardial berhubungan dengan diabetes mellitus, merokok, dan dislipidemia pada pasien penyakit jantung koroner. Merokok dapat mencetuskan akumulasi lemak visceral dan berkontribusi terhadap patogenesis resistensi insulin, juga meningkatkan risiko sindrom metabolik. Para perokok memiliki konsentrasi plasma kortisol yang lebih tinggi dibanding non-perokok yang disebabkan stimulasi aktivitas sistem saraf simpatis. Lebih jauh lagi kortisol dapat menimbulkan akumulasi lipid pada organ viseral termasuk lemak epikardial. Menopause juga merupakan salah satu hal yang dapat mempengaruhi ketebalan lemak epikardial dikarenakan hormon estrogen berperan dalam mengontrol distribusi lemak yang proporsial pada tiap area tubuh. Penelitian oleh Piordomenico dkk. Menyebutkan bahwa peningkatan gradual nilai ketebalan lemak epikardial berbanding lurus dengan komponen sindrom metabolik yang terlibat di dalamnya. Adanya faktor lain seperti aktivitas fisik, riwayat merokok, dan menopause sepatutnya diperhitungkan dalam penelitian yang mengukur hubungan antara ketebalan lemak perikardial dengan lingkar pinggang. Namun, pada penelitian ini, kami tidak mengukur variable eksternal tersebut, sehingga korelasi yang kami dapatkan bersifat lemah.. ${ }^{10}$

Hasil yang berbeda kami peroleh dari analisis IMT dengan ketebalan lemak epikardial.. Tidak didapatkan korelasi antara ketebalan lemak epikardial dan IMT $(p=0,162)$ pada penelitian ini. Hal ini sesuai dengan penelitian yang dilakukan oleh Shetty dkk. dan Dessouky dkk. IMT didapatkan dari 
perbandingan antara berat badan dengan tinggi badan kuadrat sehingga merupakan parameter untuk distribusi adipositas general, sedangkan lemak epikardial sendiri merupakan lemak viseral lokal yang terletak pada epicardium sehingga peningkatan nilai IMT tidak dapat menggambarkan peningkatan nilai ketebalan lemak viseral maupun subkutan. Pengukuran IMT tidak dapat membedakan komposisi tubuh seperti massa lemak dan non lemak. Pengukuran status gizi dengan IMT dapat memprediksi resiko penyakit tetapi tidak dapat memberikan informasi massa lemak tubuh karena mengukur keseluruhan dimensi tubuh. ${ }^{8}$ Penelitian ini memiliki beberapa keterbatasan seperti:

a. Sampel yang terlibat dalam penelitian merupakan sampel diambil secara crosssectional tanpa memandang pengaruh aktivitas fisik dan riwayat lama menderita dislipidemia,

b. Keberadaan nilai HDL yang normal pada partisipan, di mana nilai HDL yang normal dapat menjadi faktor protektif resiko kardiovaskuler sekaligus mengurangi salah satu faktor resiko metabolik lainnya,

c. Tidak ditelitinya faktor lain seperti kebiasaan merokok, ada tidaknya menopause, dan faktor lain yang berperan dalam peningkatan lemak epikardial.

\section{KESIMPULAN}

Berdasarkan hasil penelitian kami, terdapat korelasi antara lingkar pinggang dengan ketebalan lemak epikardial; yang berarti makin meningkat ukuran lingkar pinggang, makin tebal pula lemak epikardial pada pasien dislipidemia non-diabetes melitus. Sebaliknya, kami tidak mendapatkan korelasi yang bermakna antara ketebalan lemak epikardial dengan IMT.

Walaupun penelitian saat ini belum mengaitkan secara langsung ketebalan lemak epikardial dengan keberadaan penyakit kardiovaskuler, namun diharapkan penelitian ini dapat menambah literatur serta menjadi referensi pada bidang ini. Studi lanjutan dengan menambahkan karakteristik, variable eksternal, inflammatory marker, dan modalitas radiologi lainnya masih diperlukan. 


\section{DAFTAR PUSTAKA}

1. Demircelik MB., et al. Epicardial adipose tissue and pericoronary fat thickness measured with 64multidetector computed tomography: potential predictors of the severity of coronary artery disease. Clinics. 2014;69(6):388-92.

2. Salazar J., et al. Epicardial fat: physiological, pathological, and therapeutic implications. Cardiology research and practice. 2016;4(1):112-5.

3. Benedek $\mathrm{T}$., et al. The assessment of epicardial adipose tissue in acute coronary syndrome patients. A systematic review. Journal of Cardiovascular Emergencies 2017;3(1):18-29.

4. Nuttall FQ. 2015. Body mass index, obesity, BMI and health: a critical review. Nutr Today. 2015;50(3).

5. Kim SJ, et al. Correlation between epicardial fat thickness by echocardiography and others parameters in obese adolescents.

Korean Circulation Journal.

2012;3(1):28-9.

6. Chumakova GA, et al. Clinical importance of epicardial fat thickness defining in obese patients. Int $\mathrm{J}$ of Biomedicine. 2012;2(3) 161-8.

7. Song DK.,et al. 2015. Increased epicardial adipose tissue thickness in type 2 diabetes mellitus and obesity. Diabetes Metab J 2015;39:405-413.

8. Shetty $\mathrm{R}$ et al. Correlation of epicardial fat and anthropometric measurements in Asian-Indians: a community based study. Avicenna Journal of Medicine. 2012;935(1-2):40-6.

9. Bertaso $\mathrm{AG}$ et al. Epicardial fat: definition,measurements and systematic review of main outcomes. Arq Bras Cardiol. Jul; 101(1):e18-e28.

10. Piordomenico SD, et al. Epicardial adipose tissue and metabolic syndrome in hypertensive patients with normal body weight and waist circumference. Am J of Hypertension.2011;36(46):701 